ARTIKEL RISET

\title{
Pemetaan Level Literasi Kimia Peserta Didik \\ Kelas XI MIPA di SMAN 1 Lubuk Basung pada Materi Termokimia dengan Model Rasch
}

\section{Mapping the Chemical Literacy Level of Class XI MIPA Students at SMAN 1 Lubuk Basung on Thermochemistry Materials with the Rasch Model}

\author{
N Anggraini ${ }^{1}$ and E Yusmaita ${ }^{1 *}$ \\ ${ }^{1}$ Pendidikan Kimia, Universitas Negeri Padang, \\ Jl. Prof. Dr. Hamka, Air Tawar Barat, Padang Utara, Sumatera Barat, Indonesia 25171 \\ *ekayusmaita@fmipa.unp.ac.id
}

\section{ARTICLE INFO}

Received on:

15 August 2021

Revised till:

29 October 2021

Accepted on:

30 October 2021

Publisher version published on:

31 October 2021

\begin{abstract}
This study aims to analyse the mapping of chemical literacy levels of students in class XI MIPA at SMAN 1 Lubuk Basung on thermochemical material using the Rasch model according to the scientific literacy framework adapted by Shwartz. This study is a quantitative study using a sample of 50 students of class XI MIPA. The data is obtained from a chemical literacy test, then the data is analysed using the Rasch model. The results showed that students with the highest abilities have the right answers but haven't been able to define the concepts and understanding is limited, meanwhile students with the lowest ability have wrong or blank answers. Thus, it was concluded, students with the highest abilities have a functional scientific literacy level on difficult items and students with the lowest abilities have a scientific literacy level.
\end{abstract}

\section{KEYWORDS}

Chemical Literacy, Rasch Model, Thermochemistry

\section{ABSTRAK}

Penelitian ini bertujuan untuk menganalisis pemetaan level literasi kimia siswa kelas XI MIPA di SMAN 1 Lubuk Basung pada materi termokimia menggunakan model Rasch sesuai kerangka literasi sains yang diadaptasi oleh Shwartz. Penelitian deskriptif ini merupakan penelitian kuantitatif dengan sampel 50 siswa kelas XI MIPA. Data diperoleh dari tes literasi kimia, kemudian data dianalisis menggunakan model Rasch. Hasil penelitian menunjukkan bahwa siswa dengan kemampuan tertinggi memiliki jawaban yang benar tetapi belum mampu mendefinisikan konsep dan pemahamannya terbatas, sedangkan siswa dengan kemampuan terendah memiliki jawaban yang salah atau kosong. Dengan demikian, disimpulkan, siswa dengan kemampuan tertinggi memiliki level functional scientific literacy pada item sulit dan siswa dengan kemampuan terendah memiliki level scientific literacy.

\section{KATA KUNCI}

Literasi Kimia, Model Rasch, Termokimia 


\section{PENDAHULUAN}

Dari hasil survei yang dilakukan terhadap 87 orang peserta didik kelas XI MIPA di SMAN 1 Lubuk Basung TA 2020/2021 melalui platform Google Forms, didapati bahwa 90,2\% peserta didik yang mengikuti tes menyatakan pentingnya memahami materi Termokimia yang berhubungan dengan kehidupan sehari-hari. Hasil evaluasi peserta didik pada materi termokimia didapati $50 \%$ yang belum mencapai kriteria ketuntasan minimum (KKM). Terdapat beberapa faktor yang menyebabkan ketidaktercapaian KKM oleh peserta didik, diantaranya pengetahuan yang dimiliki peserta didik masih terbatas, terjadi miskonsepsi, atau peserta didik tersebut tidak memahami materi Termokimia.

Kebijakan terbaru yang dikeluarkan oleh Menteri Pendidikan dan Kebudayaan yaitu dihapuskannya Ujian Nasional (UN) dan diganti dengan kebijakan lain dalam bentuk Asesmen Kompetensi Minimum (AKM ${ }^{[1]}$. AKM digunakan untuk mengukur hasil belajar kognitif meliputi literasi membaca dan literasi numerasi ${ }^{[2]}$. Kemampuan literasi membaca dan literasi numerasi ini menjadi syarat untuk peserta didik dalam berkontribusi dalam masyarakat ${ }^{[3]}$. Hal ini dikaitkan dengan kecakapan abad 21, dimana literasi menjadi salah satu kompetensi yang harus dikuasai peserta didik agar mampu bersaing di era revolusi 4.0 $0^{[4]}$.

Kemampuan literasi yang tinggi dapat meningkatkan ilmu pengetahuan dan teknologi ${ }^{[5]}$. UNESCO (2019) menyatakan literasi tidak hanya konsep bagaimana cara membaca, menulis dan berhitung, tetapi lebih dari itu literasi merupakan salah satu sarana dalam identifikasi pemahaman, interpretasi penciptaan, komunikasi dalam dunia digital, text-mediated yang kaya akan informasi dan mengalami perubahan ${ }^{[6]}$. Literasi sains, khususnya literasi kimia merupakan salah satu kunci untuk memberikan kontribusi terhadap apa yang dibutuhkan oleh peserta didik untuk terlibat dalam masyarakat ${ }^{[7]}$.

Pada umumnya peserta didik belum terbiasa dalam mengerjakan tes kemampuan literasi atau masalah yang berhubungan dengan keterampilan berproses ${ }^{[8]}$. Orang yang memiliki literasi kimia adalah yang dapat memahami konsep dasar ilmiah dan karakteristik dari kimia dengan baik ${ }^{[9]}$. Literasi kimia diartikan sebagai sikap yang dapat menerapkan kimia dalam kehidupan sehari-hari ${ }^{[10]}$. Literasi kimia sangat berkaitan erat dengan manusia itu sendiri dari segala kalangan umur dan jenjang pendidikan $^{[11]}$.

Literasi pada peserta didik dapat diukur menggunakan level tertentu. Begitu juga dengan literasi kimia peserta $\operatorname{didik}^{[9]}$. Menurut Bybee ada beberapa level literasi kimia, yaitu: 1) Scientific illiteracy, dimana peserta didik tidak dapat bisa menghubungkan atau merespon pertanyaan yang sesuai akal tentang sains; 2) Nominal scientific literacy, peserta didik mengetahui kosakata atau isu yang berhubungan dengan sains tetapi tidak dapat menjelaskan secara bermakna dan luas; 3) Functional scientific literacy, peserta didik mampu mendefinisikan konsep dengan benar sesuai dengan apa yang mereka pahami, tetapi pemahaman mereka tentang konsep tersebut masih terbatas; 4) Conceptual scientific literacy, peserta didik memahami secara konseptual tentang konsep ilmiah dan hubungan antara konsep yang satu dengan yang lainnya, mampu berfikir ilmiah, memiliki kemampuan prosedural dan paham tentang proses inkuiri ilmiah; dan 5) Multidimentional scientific literacy, peserta didik memerlukan pemahaman konsep sains dan teknologi dari sudut pandang filosofis dan historis dan dapat mengaitkannya dengan masyarakat dan kehidupan sehari-hari ${ }^{[9]}$. Adapun aspek literasi sains PISA yang terdapat pada setiap butir soal literasi kimia untuk menentukan level literasi kimia peserta didik, dimana menuntut dalam empat aspek, yaitu aspek konteks, aspek konten, keterampilan belajar tingkat tinggi (HOLS) dan sikap (aspek afektif) ${ }^{[12]}$.

Ilmu kimia merupakan ilmu pengetahuan yang mempelajari bahan-bahan kimia, termasuk semua materi yang ada di alam sekitar, baik yang berupa bahan alami maupun bahan buatan. Ilmu kimia memusatkan kajiannya pada materi, sifat-sifat materi, struktur materi, komposisi materi, ikatan yang terjadi pada materi, perubahan materi, serta energi yang terlibat dalam perubahan materi tersebut ${ }^{[13]}$. Menurut PISA fungsi pendidikan sains, khususnya kimia untuk mempersiapkan masyarakat yang mampu berpartisipasi dalam lingkungannya untuk menghadapi perkembangan sains dan teknologi ${ }^{[14]}$.

Termokimia adalah salah satu materi pembelajaran kimia yang diajarkan di kelas XI MIPA. Termokimia merupakan ilmu yang mempelajari tentang perubahan kalor yang menyertai reaksi kimia. Materi termokimia bersifat abstrak sehingga pembelajaran tidak hanya menyampaikan tentang konsep saja tetapi guru mampu mengubah suatu hal yang abstrak menjadi konkret sehingga mampu dipahami peserta didik. Topik yang dipelajari pada materi termokimia yaitu sistem dan lingkungan, reaksi endoterm dan eksoterm, perubahan entalpi pada reaksi keadaan standar, Hukum Hess, entalpi reaksi dan kalorimeter bom ${ }^{[13]}$. Menurut penelitian yang dilakukan oleh Bir, et.al. ${ }^{[9]}$, "Penilaian kemampuan peserta didik untuk mendefinisikan beberapa konsep kimia mengungkapkan bahwa hanya sebagian kecil dari mereka yang mencapai tingkat fungsional literasi kimia, yaitu kemampuan mendefinisikan konsep dengan benar".

Analisis literasi kimia pada peserta didik dengan menggunakan butir soal literasi kimia dapat dilakukan menggunakan teori respons butir (Item Response Theory/IRT) atau disebut juga dengan model Rasch. Analisis dengan model Rasch ini menggunakan aplikasi Ministeps Rasch ${ }^{[15]}$. 


\section{METODE}

Penelitian ini dilakukan menggunakan desain penelitian deskriptif dengan pendekatan kuantitatif. Teknik analisis data menggunakan model Rasch untuk memetakan level literasi kimia peserta didik.

Subjek pada penelitian ini adalah peserta didik kelas XI MIPA di SMAN 1 Lubuk Basung TA 2021/2022. Teknik pengambilan sampel menggunakan simple random sampling sesuai dengan model Rasch, yaitu 50 orang peserta didik yang memiliki selang kepercayaan sebesar $99 \%{ }^{[15]}$.

Instrumen penelitian yang digunakan pada penelitian ini adalah butir soal berbasis literasi kimia pada materi Termokimia yang telah dikembangkan ${ }^{[16]}$. Instrumen tersebut terdiri dari 13 butir soal yang berbentuk esai. Teks wacana yang terdapat pada butir soal diantaranya adalah proses perkaratan besi, proses kalsinasi batu kapur, proses reduksi bijih besi, penggunaan amonia sebagai salah satu bahan pembuatan pupuk, proses pembakaran hutan dan garam dapur.

Soal pertama dengan teks wacana proses perkaratan, wacana tersebut berhubungan dengan penentuan sistem dan lingkungan. Berdasarkan butir soal yang diberikan peserta didik diharapkan dapat menentukan sistem dan lingkungan serta mengaitkannya dengan wacana pada soal. Teks wacana kedua tentang proses kalsinasi dan reduksi bijih besi, berhubungan dengan reaksi eksoterm dan reaksi endoterm. Peserta didik diharapkan untuk membandingkan kedua proses tersebut sehingga dapat menjelaskan perbedaan kedua reaksi.

Informasi setiap teks wacana soal dapat dilihat pada Tabel 1 yang terdiri dari satu atau dua item butir soal pertanyaan. Skor maksimum untuk setiap item butir soal adalah ada yang 2 (nominal scientific literacy), skor 3 (functional scientific literacy), skor 4 (multidimentional scientific literacy). Skor minimal setiap item butir soal yaitu 0 (scientific illiteracy). Untuk keseluruhan wacana dengan jumlah butir soal yang ada total skor nya adalah 154 . Contohnya pada teks wacana 1, yang terdapat 2 item butir soal, skor maksimumnya 20.

Teknik analisis data penelitian meliputi analisis deskriptif dan analisis data kuantitatif menggunakan aplikasi Ministep 4.8.0.0 yang meliputi:

1. Person measure; table yang ditampilkan adalah table yang merinci informasi logit dari setiap individu $^{[15]}$.

2. Person fit; table person fit akan memunculkan subjek secara berurutan yang memiliki kriteria tidak fit pada bagian atas.

3. Wright map; merupakan suatu peta yang menggambarkan persebaran kemampuan subjek dan tingkat kesukaran suatu item dengan skala yang sama ${ }^{[15]}$.

Tes yang dilakukan terhadap peserta didik menggunakan rubrik jawaban tes literasi kimia yang telah dikembangkan oleh peneliti sebelumnya. Kerangka jawaban literasi sains sebelumnya, dimana rubrik jawaban memiliki lima bagian. Pertama jika
Tabel 1. Skor Maksimum Tes.

\begin{tabular}{c|c|c} 
Teks wacana & Jumlah butir soal & Skor maks \\
\hline 1 & 2 & 20 \\
\hline 2 & 2 & 20 \\
\hline 3 & 1 & 6 \\
\hline 4 & 2 & 20 \\
\hline 5 & 1 & 6 \\
\hline 6 & 2 & 16 \\
\hline 7 & 1 & 10 \\
\hline 8 & 1 & 10 \\
\hline 9 & 1 & 6 \\
\hline 10 & 1 & 10 \\
\hline 11 & 2 & 12 \\
\hline 12 & 2 & 12 \\
\hline 13 & 2 & 6 \\
\hline \multicolumn{2}{|c|}{ Total skor } & $\mathbf{1 5 4}$
\end{tabular}

jawaban benar dan dihubungkan dengan wacana pada soal maka skor yang didapatkan adalah 4 , kedua jika jawaban benar tetapi tidak dihubungkan dengan wacana soal makan skornya adalah 3 , ketiga apabila jawaban benar tetapi penjabaran yang diberikan terbatas atau adanya kesalahan konsep maka akan mendapatkan skor 2, ketiga apabila jawaban benar tetapi tidak dapat menjelaskan jawaban maka skornya adalah 1 dan yang kelima jika jawaban salah atau kosong maka akan mendapatkan skor 0. Informasi ini dapat dilihat pada Tabel 2.

\section{HASIL DAN DISKUSI}

Butir soal literasi kimia yang telah dikembangkan oleh Kurniasih, et.al. ${ }^{[16]}$, memiliki rubrik jawaban dengan masing-masing skor yang sesuai pada deskripsi level literasi kimia yang diperoleh dari Bir et.al. ${ }^{[9]}$. Persentase hasil skor tes literasi kimia peserta didik untuk setiap item butir soal pada materi termokimia. Informasi ini dapat dilihat pada Tabel 3 .

Dari keseluruhan penjabaran persentase skor peserta didik, sebanyak $8,06 \%$ peserta didik mendapatkan skor nol, sebanyak 39,4\% peserta didik mendapatkan skor satu, sebanyak $43,1 \%$ peserta didik mendapatkan skor dua, sebanyak $21,2 \%$ peserta didik mendapatkan skor tiga dan sebanyak $1,7 \%$ peserta didik mendapatkan skor empat. Jadi dapat disimpulkan peserta didik kelas XI MIPA di SMAN 1 Lubuk Basung mendominasi dengan menjawab pada skor 2.

Contoh jawaban soal oleh peserta didik terhadap butir soal berbasis literasi kimia pada materi Termokimia. Misalnya pada butir soal proses perkaratan, salah satu sub pertanyaan adalah: "Jelaskan manakah yang bertindak sebagai sistem 
Tabel 2. Penilaian Skor Pada Rubrik.

\begin{tabular}{l|l} 
Butir soal & Skor jawaban \\
\hline $\begin{array}{l}\text { Proses } \\
\text { perkaratan } \\
\text { besi (item 1) }\end{array}$ & Salah (0) \\
\cline { 2 - 2 } & $\begin{array}{l}\text { Sistem yaitu paku berkarat, dan } \\
\text { lingkungan yaitu meja (1) }\end{array}$ \\
\cline { 2 - 2 } & $\begin{array}{l}\text { Sistem adalah paku berkarat dan } \\
\text { udara lembab. Lingkungan adalah } \\
\text { meja (2) }\end{array}$ \\
\cline { 2 - 2 } $\begin{array}{l}\text { Sistem yaitu paku berkarat dan } \\
\text { udara lembab, dimana sistem } \\
\text { merupakan yang menjadi pusat } \\
\text { perhatian. Sedangkan yang } \\
\text { menjadi lingkungan yaitu meja } \\
\text { dan alam semesta, dimana yang } \\
\text { berada diluar sistem (3) }\end{array}$ \\
$\begin{array}{l}\text { Sistem yaitu paku berkarat karena } \\
\text { terjadi reaksi antara paku dengan } \\
\text { udara lembab di atas meja dalam } \\
\text { ruangan tertutup dimana sistem } \\
\text { merupakan yang menjadi pusat } \\
\text { perhatian. Sedangkan yang } \\
\text { menjadi lingkungan yaitu meja } \\
\text { dan alam semesta, dimana yang } \\
\text { berada diluar sistem (4) }\end{array}$
\end{tabular}

Tabel 3. Persentase Skor.

\begin{tabular}{c|c|c|c|c|c}
\multirow{2}{*}{ Butir soal } & \multicolumn{5}{|c}{ Persentase skor (\%) } \\
\cline { 2 - 6 } & $\mathbf{0}$ & $\mathbf{1}$ & $\mathbf{2}$ & $\mathbf{3}$ & $\mathbf{4}$ \\
\hline Item 1 & 0 & 14 & 60 & 26 & 0 \\
\hline Item 2 & 0 & 0 & 76 & 24 & 0 \\
\hline Item 3 & 0 & 16 & 40 & 44 & 0 \\
\hline Item 4 & 0 & 26 & 38 & 24 & 12 \\
\hline Item 5 & 0 & 28 & 44 & 28 & 0 \\
\hline Item 6 & 0 & 28 & 48 & 12 & 12 \\
\hline Item 7 & 0 & 46 & 34 & 14 & 6 \\
\hline Item 8 & 0 & 60 & 40 & 0 & 0 \\
\hline Item 9 & 0 & 34 & 36 & 30 & 0 \\
\hline Item 10 & 0 & 44 & 26 & 30 & 0
\end{tabular}

dan lingkungan pada proses perkaratan paku tersebut?". Beberapa jawaban pada sub pertanyaan tersebut dapat dilihat pada Gambar 1.

Sementara itu, pada butir soal mengenai amonia, salah satu sub pertanyaan nya adalah: "Berapakah kalor yang dilepaskan untuk membentuk 1 mol gas $\mathrm{NH}_{3}$ pada tekanan 1 atm? Tuliskan persamaan termokimianya!". Beberapa jawaban peserta didik pada soal tersebut dapat dilihat pada Gambar 2 dan Gambar 3.

Berdasarkan jawaban-jawaban tersebut, diketahui kemampuan peserta didik dalam

$$
\text { Kimia. }
$$

(1)a) fistem: paluu dan uctam 2
cinghungan : meja. b.) Titah, pd pahn berhanit ada besiyang
tidah baik dikentumsi yoitu $F_{e}$, tapi
dalam ambang batas 3

(2)a)Gambor, I $\rightarrow$ reclusi elesotem, nilainy a -1 yaitu - 64 uj, terjadi pelepasan eneryi dari siltem he linghungan 3 Cambar II $\rightarrow$ reaksi endoterm. nilainya $(t)$ yaith +621 uj, teijadi penyerapan halor
duri lingunngan Leefistem.

b). Helm utuh malindungi Keepala

- Samng tangan agar terlindung dari panas - Uacamata untich melindangi mata dari perci.

- Tas pengaman tubah

(3) Diagram $a \rightarrow D H=-285$ hj, realesi elusoferm terjadi palepasan en ergi / halor 3

Diagram $b \rightarrow \mathrm{BH}=+32 \mathrm{~g}$ lJ, reaksi endoterm terjadi penyerapan energi/kalor.

$$
\begin{aligned}
& \text { (4) a.) } / \mathrm{mol} \mathrm{HHH}_{3}=\frac{-484 \mathrm{~kJ}}{2 \mathrm{~mol}}=-242 \mathrm{~kJ} / \mathrm{mol} \\
& \text { teriadi pelepasan kalor ped pembentucian amonic } \\
& \text { shg pupuh antuh penyubur tanaman } \\
& \frac{1}{2} \mathrm{H}_{2}(g)+\frac{2}{3} \mathrm{H}_{2}(g) \rightarrow \mathrm{HH}_{3}(\mathrm{~g}) \mathrm{OH}=-2 \mathrm{y}_{2} \mathrm{lj}_{j}
\end{aligned}
$$

Gambar 1. Contoh Jawaban Peserta Didik dan perolehan Skornya.

$$
\begin{aligned}
& \text { 4. a.) } 1 \mathrm{~mol} \mathrm{NHs}=\frac{-484}{2 \mathrm{~mol}} \mathrm{~kJ}=-242 \mathrm{~kJ} / \mathrm{mol} \\
& \text { adanya plleparan kalor shy nilai } g H=(-) \\
& \text { yaitu dari sistem he lingkungan, pd proses } \\
& \text { pembentukan amoniak } 4 \\
& \frac{1}{2} \mathrm{~N}_{2(5)}+\frac{2}{3} \mathrm{H}_{2}(\mathrm{~g}) \rightarrow \mathrm{NH}_{3(5)} \mathrm{SH}=-242 \mathrm{kj} / \mathrm{mol}
\end{aligned}
$$

Gambar 2. Contoh Jawaban Peserta Didik.

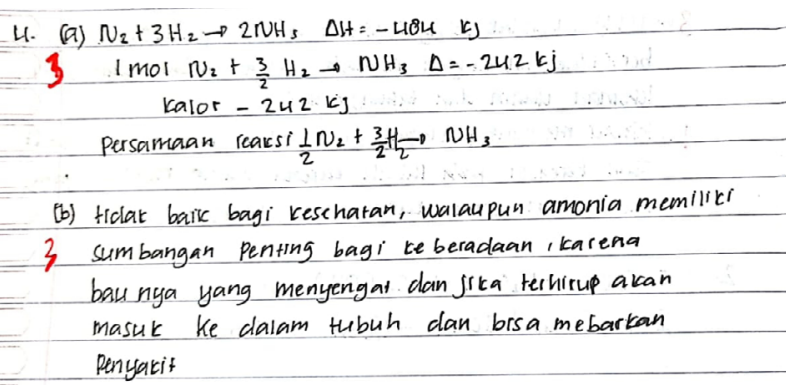

Gambar 3. Contoh Jawaban Peserta Didik. 
menjawab soal berbasis literasi kimia pada materi termokimia masih sangat terbatas dan terdapat beberapa miskonsepsi, sehingga sebagian besar peserta didik mendapatkan skor 2. Butir soal menuntut peserta didik untuk menentukan kalor yang dilepaskan untuk membentuk 1 mol gas $\mathrm{NH}_{3}$ pada tekanan 1 atm dan persamaan termokimianya, namun hanya beberapa peserta didik yang menghubungkan penjelasan jawabannya dengan jawaban yang didapat dari butir soal sebelumnya atau dari informasi yang terdapat pada teks wacana.

Berdasarkan data hasil penelitian dianalisis menggunakan aplikasi model Rasch yaitu Ministep tentang pemetaan level literasi kimia peserta didik kelas XI MIPA di SMAN 1 Lubuk Basung pada materi termokimia, didapatkan hasil sebagai berikut:

\subsection{Person Measure}

Nilai skor mentah maksimum dari rubrik jawaban butir soal berbasis literasi kimia adalah 154. Peserta didik yang memperoleh skor mentah yang sempurna, dapat disimpulkan bahwa peserta didik tersebut memahami materi termokimia pada tes literasi kimia dengan baik, namun seberapa jauh pemahaman peserta didik terhadap materi termokimia belum diketahui. Begitu juga dengan peserta didik yang mendapatkan skor mentah 0 , dapat diketahui peserta didik tersebut tidak memahami materi termokimia tersebut, namun seberapa kurangnya pemahaman peserta didik terhadap materi termokimia juga belum diketahui. Data hasil analisis person measure beberapa peserta didik. Informasi analisis data person measure dapat dilihat pada Tabel 4 .

Tabel 4. Analisis Data Person Measure.

\begin{tabular}{c|c|c} 
Subjek & Skor mentah & Nilai measure \\
\hline 01P & $55 / 154$ & 1,84 \\
\hline 03L & $53 / 154$ & 1,58 \\
\hline 08P & $51 / 154$ & 1,32 \\
\hline 18P & $47 / 154$ & 0,81 \\
\hline 25P & $33 / 154$ & $-0,87$ \\
\hline 19L & $29 / 154$ & $-1,36$ \\
\hline 42P & $25 / 154$ & $-1,86$ \\
\hline 16P & $24 / 154$ & $-1,99$
\end{tabular}

Analisis data person measure dapat menunjukkan, bahwa semakin tinggi nilai person measure peserta didik pada suatu tes, menandakan peserta didik tersebut memiliki prestasi yang lebih tinggi ${ }^{[17]}$. Kolom measure menyatakan tingkat abilitas peserta didik dalam satuan logit. Peserta didik 01P pada Tabel 4 memiliki nilai person measure paling tinggi dari peserta didik lain (measure $=+1,84$ logit), dan peserta didik $16 \mathrm{P}$ memiliki nilai person measure yang paling rendah (measure $=-1,99$ ). Adanya peserta didik yang mendapatkan nilai person measure negatif disebabkan oleh rata-rata default (parameter tetap) item measure memiliki nilai logit 0,0. Nilai negatif yang diperoleh hanya tanda bahwa peserta didik memiliki nilai person measure kurang dari mean tingkat kesulitan dari item. Jika peserta didik mendapatkan nilai person measure nya negatif pada suatu tes tidak menandakan peserta didik tersebut memiliki kemampuan yang buruk dalam suatu tes ${ }^{[18]}$.

Perbandingan kemampuan literasi kimia peserta didik dapat dilihat melalui tabel yaitu nilai person measure. Subjek 01P dan 03L memiliki selisih nilai measure 0,26. Sedangkan subjek 08P dan 18P memiliki selisih nilai measure 0,51 , artinya, antara subjek 01P dan 03P dengan subjek 08P dan 18P memiliki kemampuan literasi kimia yang berbeda. Melalui selisih nilai measure didapatkan informasi bahwa hampir dua kali lipat perbedaan tingkat literasi kimia yang diperoleh antara subjek 01P dan 03L (0,26 logit) dengan subjek 08P dan $18 \mathrm{P}(0,51$ logit), begitu juga dengan subjek-subjek lainnya.

Dapat disimpulkan bahwa nilai measure (logit) dapat dijadikan sebagai patokan untuk menentukan perbandingan kemampuan literasi kimia peserta didik kelas XI MIPA di SMAN 1 Lubuk Basung pada materi termokimia. Semakin besar nilai logit yang diperoleh maka semakin tinggi kemampuan literasi kimia peserta didik.

\subsection{Person Fit}

Analisis data person fit dapat memunculkan secara berurutan subjek yang mempunyai kriteria tidak fit dengan nilai infit dan outfit MNSQ yang tidak sesuai. Adanya nilai infit dan outfit MNSQ yang tidak sesuai menunjukkan $8 \%$ populasi dari peserta didik pada penelitian ini menunjukkan perilaku respons yang tidak sesuai. Salah satu peserta didik dengan nilai infit dan outfit MNSQ yang tidak sesuai adalah subjek 24P dengan nilai infit MNSQ 1,87 dan nilai outfit MNSQ 1,90, kedua nilai yang diperoleh oleh subjek tersebut membuktikan pola respons subjek tersebut pada tes literasi kimia tidak sesuai dengan ekspektasi yang diharapkan model. Informasi nilai infit dan outfit MNSQ dapat dilihat pada Tabel 5.

Tabel 5. Nilai Infit dan Outfit $\mathrm{MNSQ}^{[19]}$.

\begin{tabular}{c|c} 
Infit dan Outfit MNSQ & Persentase \\
\hline$>1,5$ & $6 \%$ \\
\hline$<0,5$ & $2 \%$
\end{tabular}

Pola jawaban subjek 24P mendapatkan poin 2 pada item 19 dan item 20 yang merupakan item butir soal yang termasuk sulit, tetapi pada item 1 subjek 24P mendapatkan poin 2 yang termasuk item butir soal yang mudah pada tes tersebut. Untuk mengetahui lebih lanjut kenapa subjek-subjek di atas tidak fit dengan model ideal, kita dapat menganalisis dengan skalogram untuk memeriksanya. 
Gambar 4 merupakan hasil analisis data skalogram yang menggambarkan reason person atau item, dimana item-item tersebut diurutkan dari tingkat kesulitannya dari kiri ke kanan (paling mudah ke yang paling sulit), kemudian subjek diurutkan berdasarkan kemampuannya dari atas ke bawah $^{[15]}$. Subjek 01P memiliki abilitas paling tinggi, peserta didik tersebut dapat menjawab seluruh item soal, rata-rata skor dan pola jawaban subjek 01P ini berada pada level nominal scientific literacy dan functional scientific literacy. Sementara pada subjek 24P yang menunjukkan pola respons yang unik. Pola ideal adalah jika soal yang mudah maka akan memperoleh nilai yang tinggi dan soal yang sulit akan mendapatkan skor rendah, namun subjek 24P didapatkan pola tidak fit, dimana rata-rata skor dan pola jawaban subjek 24P berada pada level nominal scientific literacy dan functional scientific literacy.

GUTTMAN SCALOGRAM OF RESPONSES: Person |Item

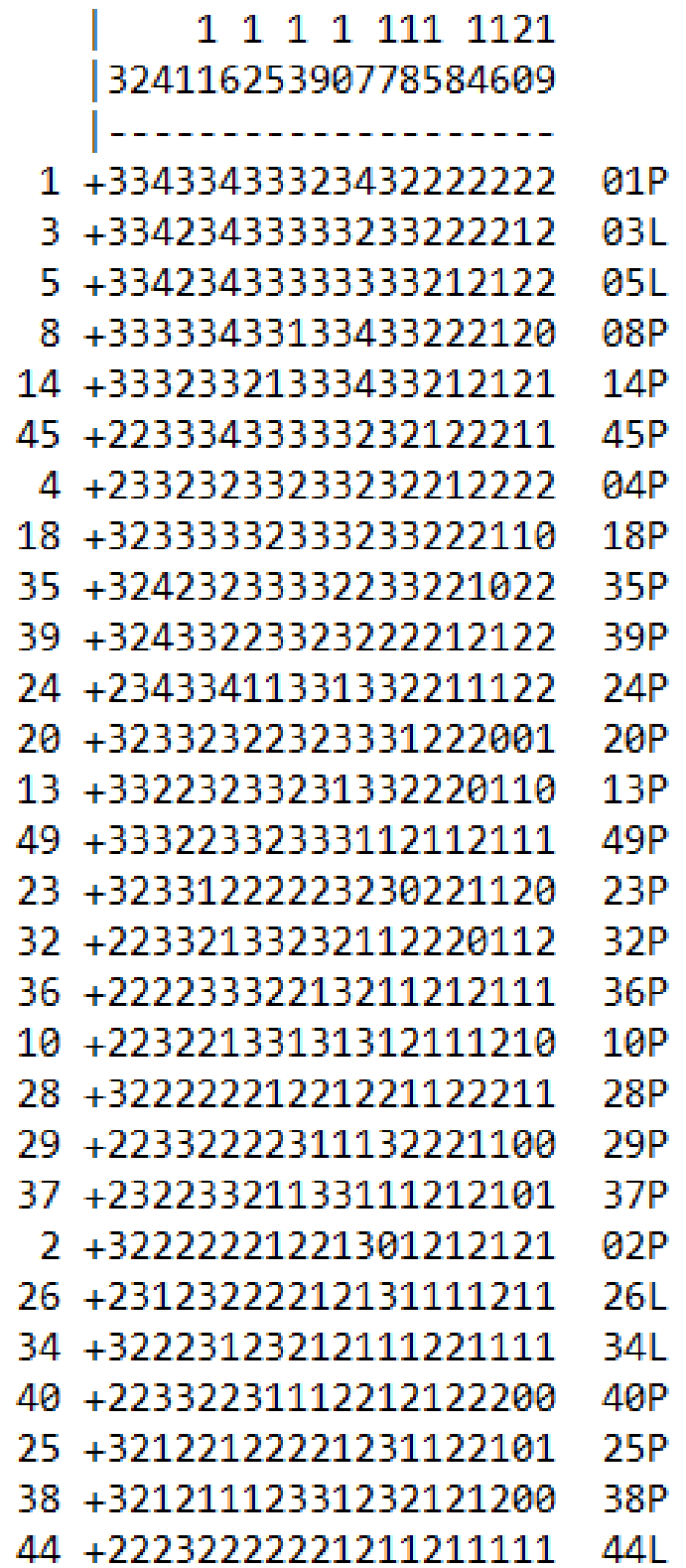

Gambar 4. Skalogram.
Analisis tingkat kesulitan item butir soal dengan tingkat kesukaran yang paling sulit sampai yang paling mudah diurutkan dari kanan ke kiri secara horizontal pada skalogram. Item butir soal yang paling sulit dijawab oleh subjek adalah item 19, yaitu subjek disuruh menghitung masingmasing perubahan entalpi pembakaran gas etana dan gas etena pada kedua reaksi yang disajikan soal. Subjek paling banyak menjawab dengan perolehan skor 1 yaitu pada level nominal scientific literacy dan functional scientific literacy.

\subsection{Wright Map}

Hasil dari pendistribusian data kemampuan peserta didik dapat dilihat melalui analisis data dengan wright map pada Gambar 5.

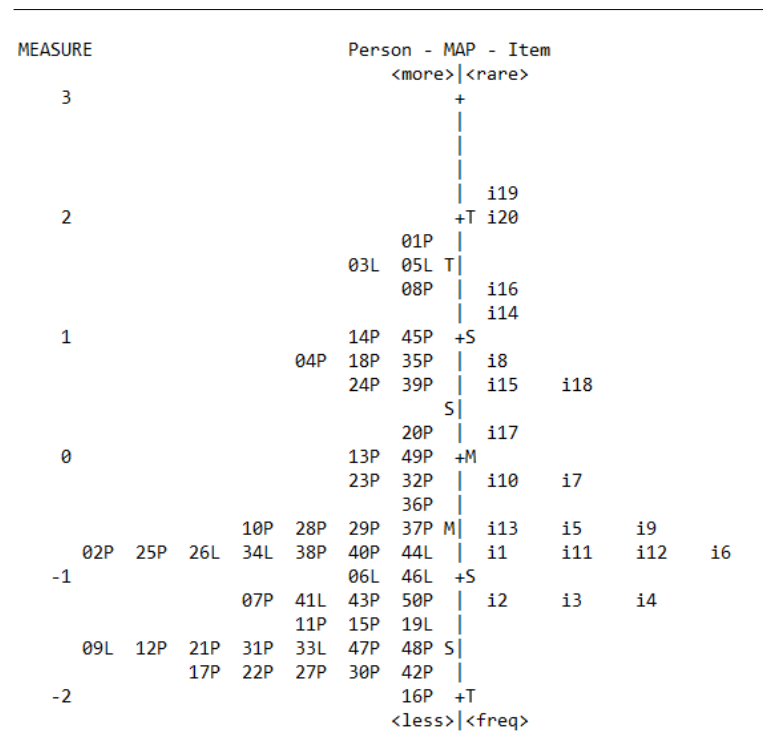

Gambar 5. Wright Map.

Analisis data wright map menggambarkan sebaran kemampuan peserta didik di sebelah kiri dan sebaran tingkat kesulitan item tes di sebelah kanan. Item yang mudah terletak pada bagian dasar Wright map dan item yang sulit terletak pada bagian puncak Wright map. Subjek atau peserta didik yang memiliki kemampuan yang rendah terletak pada bagian dasar, sementara subjek dengan kemampuan yang tinggi terletak pada bagian puncak Wright map.

Analisis data dari hasil tes peserta didik dengan Wright map yaitu, untuk item 19 (item 19) dan item 20 (item 20) termasuk yang paling sulit, dimana dari sebaran subjek tidak ada yang mencapai kedua item tersebut. Subjek dengan identitas 01P merupakan subjek yang memiliki literasi kimia paling tinggi pada butir soal yang termasuk sulit (item 16), yaitu pada level functional scientific literacy, yang dilanjutkan oleh subjek 03L dan 05L yang memiliki nilai measure sama (+1,58 logit) artinya kedua subjek memiliki kemampuan literasi kimia yang sama. Sementara itu, subjek 16P merupakan subjek dengan kemampuan literasi kimia yang paling rendah pada i16, yaitu pada tingkat scientific illiteracy. Nilai logit di atas +2 menunjukkan 
subjek memiliki kemampuan yang baik, nilai logit +1 menunjukkan subjek memiliki kemampuan yang menengah dan nilai logit -1 menunjukkan subjek memiliki kemampuan yang rendah ${ }^{[20]}$.

Penelitian pemetaan level literasi kimia peserta didik kelas XI MIPA di SMAN 1 Lubuk Basung pada materi Termokimia mendominasi skor 2 pada tes literasi kimia. Skor 2 yang diperoleh peserta didik karena jawaban peserta didik yang benar, tetapi masih banyak keterbatasan dalam menjelaskan jawaban butir soal tes tersebut.

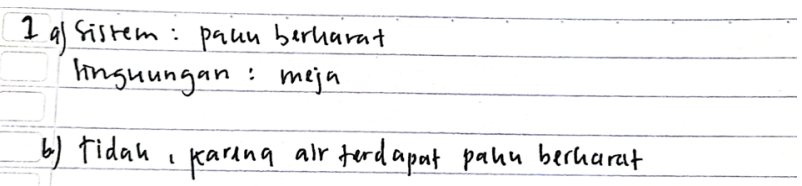

Gambar 6. Contoh Analisis Jawaban Peserta Didik.

Jawaban peserta didik adalah benar, tetapi penjelasan jawaban masih sangat terbatas, hal yang ditanyakan yang menjadi sistem dan lingkungan dari wacana soal proses perkaratan yang diberikan, pada jawaban peserta didik hanya menjawab meja sebagai lingkungan, padahal yang menjadi lingkungan dari suatu peristiwa tidak hanya meja tetapi alam semesta juga bertindak sebagai lingkungan pada Gambar 6 . Pada sub pertanyaan kedua, ditanyakan "jika dalam suatu bak air minum terdapat suatu paku yang sudah berkarat, apakah air dalam bak tersebut boleh direbus dan digunakan untuk minum?". Jawaban peserta didik hanya terbatas menjawab tidak dengan alasan yang tidak dikaitkan dengan wacana pada soal.

Analisis data dengan Wright map, diketahui subjek dengan kemampuan tinggi memiliki level literasi kimia pada butir soal sulit di tingkat functional scientific literacy dan subjek dengan kemampuan terendah tidak memiliki kemampuan level literasi kimia atau disebut sebagai scientific illiteracy. Perolehan level literasi kimia peserta didik pada tes ini, dapat dipengaruhi oleh ketidakpahaman peserta didik terhadap materi termokimia yang telah dipelajari, hal ini sesuai dengan hasil survei terhadap peserta didik kelas XI MIPA di SMAN 1 Lubuk Basung TA 2020/2021.

Hasil penelitian yang dilakukan oleh Shwartz ${ }^{[9]}$ mendukung penelitian ini, yaitu: "hanya sebagian kecil peserta didik yang mencapai level functional scientific literacy", dimana level tertinggi yang mampu peserta didik capai pada item butir soal yang sulit pada materi termokimia. Materi termokimia ini juga merupakan salah satu materi bersifat abstrak dimana pembelajaran tidak hanya menyampaikan tentang konsep saja ${ }^{[13]}$. Selain itu, ini merupakan kali pertama peserta didik kelas XI MIPA di SMAN 1 Lubuk Basung TA 2021/2022 mengerjakan soal berbasis literasi kimia, sehingga pernyataan Winata et.al. ${ }^{[8]}$, yaitu "umumnya peserta didik belum terbiasa dalam mengerjakan tes kemampuan literasi atau masalah yang berhubungan dengan keterampilan berproses" juga mendukung hasil penelitian ini.

\section{SIMPULAN}

Pemahaman konsep peserta didik kelas XI MIPA di SMAN 1 Lubuk Basung pada materi termokimia sangat memengaruhi literasi kimia pada peserta didik. Berdasarkan hasil analisis data, pemetaan level literasi kimia peserta didik dengan kemampuan paling tinggi pada item butir soal yang sulit (item 16) adalah pada level functional scientific literacy, dimana peserta didik belum mampu mendefinisikan konsep dengan benar sesuai dengan apa yang dipahami dan pemahaman mereka tentang konsep tersebut masih terbatas. Sementara itu, peserta didik dengan kemampuan paling rendah pada butir soal yang sama yaitu tidak memiliki kemampuan literasi kimia (scientific illiteracy) dimana peserta didik tidak dapat menghubungkan atau merespon pertanyaan yang sesuai akal tentang sains. Agar kemampuan literasi kimia peserta didik dapat ditingkatkan, disarankan untuk melakukan penelitian mengenai model, metode dan media pembelajaran yang dapat diimplementasikan untuk meningkatkan level literasi kimia peserta didik.

\section{REFERENSI}

1. Dewi PA. Berliterasi Sejak Dini untuk Menghadapi Asesmen Kompetensi Minimum. J Pendidik Budaya War Pendidik 2021;5(5):4-5.

2. Rokhim DA, Rahayu BN, Alfiah LN, Peni R, Wahyudi B, Wahyudi A, et al. Analisis Kesiapan Peserta Didik dan Guru Pada Asesmen Nasional (Asesemen Kompetensi Minimum, Survei Karakter, dan Survei Lingkungan Belakajar). J Adminitrasi dan Manaj Pendidik 2021;4:61-71.

3. Aisah $\mathrm{H}$, Zaqiah QY, Supiana A, Islam U, Sunan N, Djati G. Implementasi Kebijakan Asesmen Kemampuan Minimum (AKM): Analisis Implementasi Kebijakan AKM). J Pendidik Islam Al-Affan 2021;1(2):128-35.

4. Nurjanah E. Kesiapan Calon Guru SD dalam Implementasi Asesmen Nasional. J Papeda 2021;3(2):76-85.

5. Laksono PJ. Studi Kemampuan Literasi Kimia Mahasiswa Pendidikan Kimia Pada Materi Pengelolaan Limbah. Orbital J Pendidik Kim 2018;2(1):1-12.

6. Prastiwi MNB, Rahmah N, Khayati N, Utami DP, Primastuti M, Majid AN. Studi Kemampuan Literasi Kimia Peserta Didik pada Materi Elektrokimia. Pros Semin Nas Kim UNY 2017;21:101-8.

7. Bay JL, Vickers MH, Mora HA, Sloboda DM, Morton SM. Adolescents as agents of healthful change through scientific literacy development: A school-university partnership program in New Zealand. Int J STEM Educ 2017;4(1).

8. Winata A, Sri C, Seftia I. Analisis Kemampuan Awal Literasi Sains Mahasiswa Pada Konsep IPA. Educ Hum Dev J 2016;01(01).

9. Shwartz Y, Ben-Zvi R, Hofstein A. The use of scientific literacy taxonomy for assessing 
the development of chemical literacy among high-school students. Chem Educ Res Pract 2006;7(4):203-25.

10. Thummathong R, Thathong K. Chemical literacy levels of engineering students in Northeastern Thailand. Kasetsart J Soc Sci 2018;39(3):478-87.

11. Sujana, A, Permanasari A. Literasi Kimia Mahasiswa PGSD dan Guru IPA Sekolah Dasar. Jurnal Pendidikan IPA Indonesia 2014;3(1):5-11.

12. OECD. PISA 2015 Framework. Oecd 2013;(March 2015):52.

13. Brady JE. Chemistry The Molecular Nature of Matter. 2012.

14. Yusmaita E, Nasra E. Perancangan Assesmen Literasi Kimia Dengan Menggunakan Model of Educational Rekonstruction (MER) Pada Tema: "Air Sebagai Pelarut Universal.” J Eksakta Pendidik 2017;1(2):49.

15. Sumintono B. Rasch Model Measurements as Tools in Assesment for Learning. 2018;173(ICEI 2017):38-42.

16. Afifah S, Yusmaita E. Perancangan Assesmen Literasi Kimia Pada Materi Termokimia Kelas XI SMA/MA. Edukimia 2019;1(3):84-9.

17. Fakhriyah F, Masfuah S, Roysa M, Rusilowati A, Rahayu ES. Student's science literacy in the aspect of content science? J Pendidik IPA Indones 2017;6(1):81-7.

18. Boone WJ, Yale MS, Staver JR. Rasch analysis in the human sciences. 2014.

19. Sumintono B. Model Rasch untuk Penelitian Sosial Kuantitatif. ITS Surabaya 2014;(November 201):1-9.

20. Ibnu, M., Indiyani, B., Inayatullah, H., \& Guntara Y. Aplikasi Rasch Model: Pengembangan Intrumen tes untuk Mengukur Miskonsepsi Mahasiswa Matematika pada Materi Mekanika. Pros Semin Nas Pendidik FKIP 2019;2(1):205-10. 